\title{
O CULTO A CIBELE EM TERTULIANO E MINÚCIO FÉLIX
}

\author{
MARIA MARTHA PIMENTEL DE MELLO \\ Fundação Casa de José Américo
}

\begin{abstract}
Resumo: $O$ culto a Cibele foi implantado no território Romano em 205-204 a.C., funcionando ininterruptamente, por seis séculus, até o triunfo do cristianismo. Seu ritual exótico despertava curiosidade e atraia seguidores, sobretudo mulheres, impedidas de participarem do culto mitráico. Apesar de sofrer restriçóes periodicas, atingiu maior importancia como o imperador Cláudio, que o prestigiou por considerá-lo menos perigoso que o culto isłaco. Tertuliano e M. Félix, em suas obras apolagéticas, condenaram esse culto e sobretudo o seu ritual. Utilizando argumentos semelhantes, ou mesmo com colocaçóes diferentes, visavam ao objetivo comum que consistia em inocentar os cristáos das penalidades impostas por náo participarem dos cultos da religiâo oficial, principalmente aqueles dedicados ao imperador.
\end{abstract}

Palavras-chave: História romana; Mitologia clássica; Religiáo romana; Cristianismo; Paganismo.

1. O culto aos deuses romanos, imposto aos povos conquistados, por ocasião da expansão das fronteiras do Império Romano, funcionou como elemento de romanização, juntamente com as instituiçōes políticas. Como exemplo da implantação desses cultos nos territórios incorporados ao Império, citamos o culto ao imperador ', após a reforma religiosa da Augusto ${ }^{2}$. Ressaltamos que o processo de adoção de cultos aos deuses romanos não constitui um fenômeno unilateral. A implantação de cultos orientais ${ }^{3}$, em Roma e na península Itálica, marcou o aspecto bilateral desse fenômeno, verificando-se perfodos em que fluiam, com plena liberdade e outros marcados por perseguiçōes. Essas perseguições comprovam a importância alcançada pelos deuses orientais, entre os romanos. Em várias ocasiōes, o governo estabeleceu regras destinadas a adaptar esses cultos às peculiaridades da religiäo oficial" 3 .

O culto a grande Mãe foi implantado em Roma em 205-205 a.C., sendo-lhe erigido um templo entre os mais tradicionais deuses romanos 5 . Apesar de sofrer algumas restrições, fun-

1. Sobre o culto ao imperador, CUMONT, 1987, p. 32, destaca que foi o único dos cultos oficiais imposto a todos os súditos como prova de lealdade, sublinhando sua origem asiática e representando a mais pura tradiçáo da monarquia orlental. Ver também, entre a extensa blbliografia: Bayet, 1984, p. 187 ss.; idem, 1977, p. 275-352; Bolssier 1974, p. 315 ss; Toutain, 1967, p. 227 ss.; Cid Lopes, M. R. 1986, passim; Mangas, 1980, p. 419.

2. Sobre a reforma religlosa realizada por Augusto existe uma ampla bibliografia. Entre outras obras, ver: Cumont, 1987 , p. 43; Glay. 1971, p. 46 ss.; Boisser, 1974, p. 137 ss.; Lambrechts, 1947, p. 191, ve o culto imperial como elemento que fortalece o regime e acelera a aceitaçăo das instituiçőes romanas; Albertini, 1970, p. 156.

3. Sobre os cultos orientais introduzidos em Roma, ver: Beaujeu, 1955, p. 28 ss. e 34, destaca que a decadéncia da ltália favoreceu a adoçáo desses cultos, por influência dos soldados, marinheiros $\theta$ comerciantes, produzindo sincretismos que satisfaziam a todos. Ver também Gasparro 1982, p. 473; Burckhardt, 1982, p. $159,183$.

4. As novas divindades introduzidas em Roma eram veneradas por numerosos súditos do Império, depois de se normalizar o funcionamento do colégio sacerdotal atravós das regras ditadas pelo governo. Sobre o tema, ver: Cumont, 1987, p. 31-32, 70-71; Carcopino, 1941, p. 70-71; Beaujeu, 1955, p. $314 \mathrm{~s}$.

5. Merece recordar que Cibele foi instalada no Palatino, enquanto Apolo era mantido fora do pomerium sagrado, no campo de Marte. Sobre o tema, ver Pensabene, 1972, p. 72 ss. 
cionou sistematicamente até o triunfo do cristianismo, o que permite seguir seu funcionamento no território romano, durante seis séculos ${ }^{6}$. O prestígio que desfrutou esse culto pode ser explicado pela crença em Cibele haver salvado os romanos do dominio cartaginês ${ }^{7}$. Apesar dó isolamento a que foi submetido o culto, sua permanência no pomerium parecia afastar qualquer influência sobre seus adeptos. Ao imperador cabia a aprovação das honrarias prestadas pelo colégio sacerdotal, composto pelos sacerdotes frígios.

O imperador Cláudio promoveu o culto a Cibele por considerá-lo menos perigoso que o culto a Ísis, uma vez que, em século e meio não havia pertubado a ordem; seu exótico ritual apenas despertava curiosidade e atraia seguidores. A situaçāo de legalidade, que o amparava motivou sua união com outros cultos orientais que objetivavam desfrutar de sua proteção, proteção essa que implicava em obrigaçōes mútuas. (Cumont, 1987, p. 58). Esta situação gerou sincretismos ${ }^{8}$, uma vez que Cibele e Átis representavam numerosas divindades recém-chegadas à península e cultuadas por adeptos dos mais diferentes niveis sociais.

A difusão de cultos orientais, em Roma, deve-se à intensificação dos contatos com o Oriente, através das tropas romanas e da introdução de escravos orientais como conseqüência das guerras de conquista. Nảo podemos esquecer que esses cultos despertavam, na população, o desejo de busca de novas emoçōes ${ }^{9}$ não oferecidas pela religião oficial e encontradas em alguns cultos orientais. Segundo E. R. Dodds (Dodds, 1975, p. 141) "... para os povos do Império foi uma época de crescente insegurança e miséria". Refere-se Dodds à primeira metade do século III, possivelmente depois que Tertuliano escreveu o Apologeticum e durante a época de M. Félix ${ }^{10}$.

2. Tertuliano e M. Félix em suas obras apologéticas concenam o culto à Cibele, postura diferente da adotada por Justino que evita atacar esse deusa. Os primeiros apologistas citados, utilizando argumentos semelhantes ou fazendo colocações diferentes, chegam as mesmas conclusões. O repúdio à prática da castração, importante componente do ritual cibeliano, constitui uma das acusações mais freqüentes. Essa prática remonta à antiga origem do culto, quando os frígios, oriundos da Trácia e seguindo a tradição pagã, promoveram o sincretismo entre os deuses locais e os trácios. A grande Deusa da Terra foi colocada ao lado de Mã ou de Cibele e Átis foi associado a Dionísio-Sabazio. Os barulhentos cortejos (Catulo, Poesias, LXIII), formados pelos sacerdotes e fiéis que simbolicamente seguiam a deusa em suas lamentações pela morte prematura do amante, culminavam com o espetáculo sangrento dos Galli 11 que se mutilavam, em uma atitude de imitação ao deus e com o objetivo de alcançar o êxtase.

Destacamos duas passagens em que os apologistas, objetivando diminuir a importância do culto prestado a Cibele, condenam as mutilações praticadas pelos Galli e devotos da deusa, relacionados com o antigo mito.

Tertuliano no Apologeticum (Tertuliano, Apologeticum XXIII, 3) repudia a prática das castrações ${ }^{12}$ e sem citar a deusa, condena a inclusão deste costume nos rituais de alguns cultos

6. Sobre a continuidade do culto dedicado a Cibele durante o Império, ver: Beaujeu, 1955, p. 312; Bianchi, 1982, p. 9.

7. A ajuda prestada por Cibele aos romanos está comentada, entre outros autores, por: Seemann, 1958, p. 196; Burckhardt, 1982; p. 146.

8. Sobre o sincretismo de Cibele com outras deusas, ver: Conti, 1988, p. 674; Rose, 1973, p. 53, 166; Beaujeu, 1955, p. 319; Cumont, 1987, p. 62.

9. As manifestaçס̌es de emoçåo no culto a Cibele, encontram-se tratadas, entre outros autores, por: Seemann, 1958, p. 196; Beaujeu, 1955, p. 27 ss.; Frazer, 1986, p. 412; Carcopino, 1941, p. 167-8, alude ao momento diffcil em que o imperador Cláudio assumiu o mandato do império quando o aspecto moral dos romanos atravessava uma crise produzida pelo desenvolvimento das consciências e o choque de crença: Dodds, 1975, p. 22; Briem, 1951, p. 30; Burckhardt, 1982, p. 22.

10. A discussåo sobre a data do Octavio, de M. Fôlix está muito bem tratada na introduçăo à traduçăo feita por Beaujeu, 1974.

11. O processo de castraçăo a que se submetiam os galli, além do sentimento de desprezo que provocava entre os romanos, era considerado crime, portanto, punível segundo a legislaçåo romana. Dig. XLVIII, 3, 4, 2. Considera-se que a prática da castraçăo também era frequénte entre os cristăos, como afirma: Dodds, 1975, p. 56-57; Briem, 1951, pi 298, 316; Toutaln, 1967, p. 83 ss., 93.

12. A prática da castraçăo entre os que cultuavam Cibele e Átis encontra-se bem estudada por Carcopino, 1941, p. 76-109, que aclara as diferenças entre os galli e os archigalli, afirmando serem os primeiros, frígios, estrangeiros bárbaros e os segundos, romanos civilizados: Plutarco, Marcion, 17; Frazer, 1986, p. 404 s.; Turcan, 1983, p. 45. 
religiosos. Argumenta que não se trata de atitude ditada pelo deus, mas pelo diabo, prosseguindo no propósito de negar a categoria divina dos deuses pagãos. Insistindo no comportamento diferenciado de deuses e demónios, irônicamente registra que os que se suicidam saltando do teto de um templo foram impelidos pelos deuses, enquanto aqueles que se suicidam saltando do teto do vizinho cometem falta grave e foram influenciados pelos demônios.

Ao reprovar o comportamento amoroso de Cibele (Tertuliano, Apologeticum, XV, 2) destaca que a deusa suspira por ter sido desdenhada por um pastor e acusa os atores de pantomina de revelarem as torpezas dos deuses pagãos, já que divulgam episódios indignos dos deuses. Ora, o autor acusa duplamente a deusa: primeiro, por apaixonar-se por quem não a merece e depois, por ser incapaz de despertar o sentimento de amor. Para ressaltar a importância da deusa destaca sua incapacidade para fazer-se amar pelo mortal que lhe desperta forte paixão. Dirige seu discurso para comprovar a falta de onipotência ${ }^{13}$, categoria cristã indispensável à divindade. Paralelamente, acusa aos pagãos, explicitamente aos poetas e implicitamente aos que o escutam, de riem-se nos espetáculos onde se falta com respeito aos deuses, já que suas fraquezas são utilizadas para divertir o público. Novamente, o apologista toma como parâmetro outra categoria cristã - a perfeição divina - que não se coaduna com os princfpios do paganismo, uma vez que os deuses pagãos conservam as mesmas qualidades e defeitos dos homens, apresentando como diferença, apenas a imortalidade.

Minucio Félix (Félix, M. Octávio, XXII, 4) diz que se envergonha de falar de Cibele, deusa que mutilou seu amado, tornando-o um eunuco, por năo ser correspondida em seu amor, devido ao seu aspecto disforme e sua velhice ${ }^{14}$. Registra dessa forma a origem da prática das castrações afirmando que os galos a adotaram, a partir desta fábula.

Portanto, ao acusar a deusa de mutilar seu amado, como castigo por não ser correspondida em seu amor, em conseqüência de sua velhice, nega também, indiretamente, a categoria divina, uma vez que a avançada idade, constitui etapa vital que não atinge os imortais ${ }^{15}$. No entanto, o que realmente vemos enfatizado é repúdio à prática das castraçōes, sob a acusação de que a deusa divinizou um eunuco, segundo a fábula e contribui para a inclusāo de torturas ${ }^{16}$ em seus rituais. Observamos que esse autor, em um único comentário, reúne a idéia das duas citaçōes de Tertuliano sobre a impotência da deusa em face do amor frustrado e o processo de castração a que eram submetidos os sacerdotes e os iniciados no culto.

A crftica dos apologistas sobre o processo de castração, além das acusações expllcitas, implicitamente condena o culto à Cibele. Atacando o ritual, responsabiliza a deusa por introduzir essa prática e conduzir seus adpetos à mutilação, sob a alegação de conseguir maior identidade com o deus. Justino não faz alusão às castraçōes, mas cita o exemplo de um cristão que se propós a praticá-la para provar o comportamento casto dos cristãos; pela forma como se expressa, parece aprovar tal prática (Justino, Apologia, I, 29).

A ajuda prestada pela grande mãe dos deuses romanos 17 está registrada pelos dois apologistas. Tertuliano (Tertuliano, Apologeticum, XXV, 4) diz que Cibele sentia forte paixão por Roma, recordando a cidade que ela havia defendido dos ataques aqueus. Em face de sua dedicaçăo aos troianos e sabendo que os romanos haveriam de conquistar a Grécia, vencedora da Frigia, apoia os romanos na luta contra os cartagineses. M. Félix (Félix, M. Octávio, VII, 3)

13. Sobre os poderes da deusa, ver: Toutain, $1967,2^{\circ}, p .76$. Observa-se que a idéia da onipotencia e santidade divinas fol introduzida na religibo greco-romana ao mesmo tempo que os deuses orientals. Burckhardt, 1982. p. 130 ss.

14. Sobre a ampla bibliografia que trata do mito de Átls, ver: Cosi, 1982, p. 485-504; Seemann, 1958, p. 196-7; Rose, 1973, p. 169 ss.; Carcopino, 1941, p. 49-171; Beaujeu, 1955, p. 317; Gasparro, 1982, p. 475-6; Cumont, 1987, p. 55 ss; Frazer, 1986, p. 402 ss.; Burckhardt, 1982, p. 160 s.; Lambrechts, 1952, p. 141-70; Turcan, 1983, p. 42 ss,; Briem, 1951, p. 302 8. 309 s.

15. A concepçáo de humanidade entre os romanos, a partir de Marco Auréllo, está descrita por Dodds, 1975, p. 27-33; Cumnont, 1987, p. 64,110, 115; Frazer, 1986, p. 413.

16. Sobre a tortura praticada pelos pagåos $\theta$ cristăos ver: Dodds, 1975, p. 52-3, 60; Burckhardt, 1982, p. 161, destaca que no seculo IV a adoça do sequito de eunucos entre os romanos fol consequencia da aceitaclo do culto friglo da grande deusa; sobre as torturas ver a mesma obra, p. 195, 214.

17. Vor nota 7. 
limita-se, em seus comentários, a dizer que a Mãe do monte Ida salvou a cidade do sobressalto dos inimigos e provou a castidade de uma mulher.

Vemos que M. Félix refere-se rapidamente, à vitória dos romanos sobre os cartagineses, utilizando um argumento mais próximo a sua época. Considera mais eficaz evidenciar um acontecimento que faz parte da memória coletiva, ligado ao início do culto em Roma, sem aludir ao conhecimento futuro, por parte da deusa. Tertuliano utiliza um acontecimento muito antigo, remontando-se aos inícios da história grega - a conquista de Troia ${ }^{18}$ - pretendendo, com uma argumentação forçada, mostrar que a deusa conhecia o futuro e que sua ajuda aos gregos seria vingada, muito tempo depois, com a vitória dos romanos sobre os gregos. Sua exposiçāo, permeada de ironia, culmina com o reconhecimento da sabedoria de Cibele. Está claro o jogo utilizado pelo autor, admitindo ou refutando o que Ihe interessa em cada momento especffico.

Em outra passagem Tertuliano (Tertuliano, Apologeticum, XII, 4) manifesta-se ironicamente sobre a deusa quando lamenta que os cristãos sejam arrojados às feras e em seguida registra que estas mesmas feras figuram ao lado de Libero, de Cibele e de Ceres. Sabemos que a preocupação maior dos apologistas consistia em livrar os cristãos dos castigos recebidos, por não participarem dos cultos pagãos. Assim, a comparação entre a presença dos cristãos na arena, sendo arrojados às feras e o fato de Cibele ser representada em um carro puxado por leões ${ }^{19}$, enquadra-se perfeitamente na contestação. Por outro lado, retrata, com amarga ironia, o desprezo do autor pelos deuses pagãos.

Ambos autores aludem aos poderes sobrenaturais ${ }^{20}$, na época atribuldos não somente aos deuses, mas também aos daímones. M. Félix (Félix, m. Octávio, VII, 3) faz referência a um milagre da deusa por ocasião de sua chegada à Roma (já citado), quando livrou a cidade do assalto dos inimigos e provou a castidade de uma senhora ${ }^{21}$.

Tertuliano (Tertuliano, Apologeticum, XXV, 5-6) destaca que, em seus tempos, Cibele documentou sua onisciência por ocasião da morte do imperador Marco Aurélio. Relata que na cidade de Sirmio o sacerdote da deusa sacrificou pela saúde do imperador, sete dias após sua morte. Com sua tônica de ironia, acusa os correios de serem lentos e retardar a notícia da morte do imperador, propiciando, assim, com sua ineficiência, motivos aos cristāos para rirem-se da deusa.

Vemos que M. Félix limita-se a narrar a tradição, evitando maiores críticas. Tertuliano, ao contrário, insiste na ausência dos poderes sobrenaturais da deusa quando comenta o desconhecimento da morte do imperador Marco Aurélio, tanto por parte de Cibele como também de seu sacerdote ${ }^{22}$. Ironicamente, encerra seus comentários com acusaçōes à ineficiência dos correios. Mais uma vez, o autor utiliza um parâmetro cristão para julgar o paganismo. M. Félix (Félix, M. Octávio, XXV, 9) retoma o tema e citando Cibele e outros deuses acusa a deusa de maior fidelidade aos seguidores do culto que aos romanos, assinalando seu descompromisso com os romanos.

3. O culto a Cibele foi o primeiro dos cultos orientais a ser introduzido em Roma. Sua adoção deve-se a determinação das Sibilas ${ }^{23}$ que anunciaram a introdução desse culto, em

18. Tertuliano referese a derrota de Tróia, quando Enéias com sua famflia, por Indicaçáo de Jáplter, abandona a cidade em drreçăo dos bosques de Ida, dirigindo-se depois á peninsula Itálica. Sobre o tema existe uma ampla blbliografía que entre outros pode-se ver: Meunler, s/data, p. 226 ss.; Beaujeu, 1955, p. 45, 312; Virgflio, Eneida, XII; Steudling, 1934, p. 181.

19. A representaçăo de Clbele, puxada por ledes 6 a forma usual. Sobre o tema, ver: Seemann, 1958, p. 196; Stella, 1956, p. 16: Toutain, 1967, II, p. 77; Beaujou, 1955, p. 312-3; Briem, 1951, p. 301.

20. Dodds, 1975, p. 61 ss. faz uma excelente reflexăo sobre as experiencias extraordinárlas realizadas nos seculos II e III, utllzando o Simpósio de Platáo para definir o demonlaco como poder mediador e ánico intermediário entre Deus e os homens. Destaca essa visáo dos dalmones como uma novidade na época de Platáo e como uma Id́la comum no século ll. Portanto os apologistas nåo săo inovadores sobre essa idéla; limitam-se a refletir o pensamento geral de sua epoca; ver também Burckhardt, 1982, p. 182.

21. Sobre o milagre realizado por Cibele provando a castidade de Cláudia Quinta, ver Turcan, 1983, p. 48.

22. Os sacriffclos realizados por ocasiăo da morte do Marco Auréllo, de que fala Tertuliano, está comentado por: Toutaln, 1967, p. 94: Carcopino, 1941, p. 53-4, 79-80.

23. As Sibilas, profetlsas orlundas da Ásla Menor, conhecidas como as mals sáblas em evitar desgraças, depols de consultar seus Itvros sagrados, anunclaram que a introduçáo do culto a deusa frígla, em Roma, era a única fórmula para obter a viı́ria sobre Anlbal. Sobre o tema ver. Seemann, 1968, p. 196; Briem, 1951, p. 298; Burckhardt, 1982, p. 298. 
Roma, como única forma capaz de propiciar a vitória dos romanos sobre Anibal ${ }^{24}$. Podemos determinar dois momentos diferentes no estabelecimento desse culto. Inicialmente a chegada da deusa a Roma, durante a República, foi comemorada com grandes festejos e a concessāo das honrarias máximas, mas sem contar com muitos adeptos. Para F. Cumont o pequeno número de seguidores justifica-se, em virtude de novo culto ter sido introduzido por determinação do Senado e por "contrastar violentamente com a religião oficial e excitar perigosamente as mentes (Cumont, 1987, p. 53; Seemann, 1958, p. 196; Burckhardt, 1982, p. 179). Como conseqüência dessas medidas, os sacerdotes eram obrigatoriamente frígidos e os jogos Megalenses ${ }^{25}$, realizados em honra a deusa, foram reestruturados e adequados às tradiçōes da religiāo oficial. Dessa forma, o culto a Cibele permaneceu sem relevância durante a época republicana, mas desfrutando das maiores honrarias, o que se comprova pela presença do templo no pornerium.

Durante o Império observa-se uma evolução diferente, motivada pelas influênicas orientais e pela ausência de qualquer restrição ao culto. $O$ imperador Cláudio ${ }^{26}$ fortaleceu 0 antigo culto dedicado a Cibele, possivelmente para frear o prestígio crescente da deusa egípcia İsis ${ }^{27}$. O culto a grande Mãe recuperou suas antigas características "bárbaras", difundindo-se rapidamente em Roma e nas mais longínquas províncias do Império.

Esse culto está inserido nas religiōes de salvação que extendem a imortalidade aos seguidores fiéis, em contra-posição com o caráter classista ${ }^{28}$ da religião oficial que concede esse privilégio a pouquíssimos romanos. Por outro lado, seus ritos e cultos extravagantes e cheios de segredos, despertam o interesse em uma época de intranqüilidades, quando a inquietação das mentes poderia ser satisfeita com a adesão a um desse cultos ${ }^{29}$. Uma ampla participação no culto prestado a Cibele poderia saciar os espíritos, ocupando o vazio em que os romanos encontravam-se imersos.

Deve-se ter presente que a grande credibilidade do culto a Grande Mãe dos deuses foi motivada pela vitória dos romanos sobre os cartagineses, responsável pela mudança radical dos resultados da guerra. Essa nova situação foi relacionada com a chegada da deusa à Roma, em retribuição à grande ajuda recebida. $O$ agitado culto, celebrado anualmente em sua honra, exercia grande atração sobre os romanos, desacostumados ao ritual pomposo que culminava com a celebração a portas fechadas ${ }^{30}$, despertando, além de forte curiosidade, 0 desejo intenso de conhecer os mistérios, tão sigilosamente guardados.

4. Antes de concluir estas observações sobre o estudo do culto dedicado a Cibele, através dos apologistas, é interessante questionar em que segmentos da sociedade enquadravam-se os devotos da deusa.

Segundo F. Cumont (Cumont, 1987, p. 53), quando o Senado se deu conta do culto

24. A ameaça de Anßbal, mantendo-se próximo à Roma no ano 205 a.C., motivou o cumprimento das determinaçరes das Sibilas, transferlndo-se para Roma a pedra negra de Pesinunte, considerada morada da deusa e cedida à Roma pelo rei Atalo, de Pérgamo. A vitória romana sobre Anfbal, obtida no mesmo ano, ascendeu a deusa ao pantelo romano, o que lhe concedeu grandes honras, inclufda a construçáa de um templo no Palatino e a instituiçăo de jogos comemorativos em sua honra.

25. Os jogos em honra a deusa foram estabelecidos desde sua chegada à Roma, a 2 de abril, como festa permanente presidlda pelo pretor. Sobre o tema, ver: Seemann, 1958, p. 196; Frazer, 1986, p. 404; Briem, 1951, p. 298.

26. Segundo Bayet, 1984, p. 229, foi imperador Cláudio, quem ofereceu total liberdade ao culto a Cibele em Roma. Sobre o tema, ver: Carcopino, 1947, p. 49-111, onde trata exaustlvamente da importância obtida por esse culto na época de Cláudlo, destacando porém a possibllidade da mudança ter sido realizada por outros imperadores; Lambrechts, 1952, p. 141-170; Frazer, 1986, p. 299, 307; Dorem, 1953, p. 79-88; Beaujeu, 1955, p. 36s., 45, 270, 316-7, mantém-se a favor de Antonino como o imperador que normalizou o culto a cibele com a instituiçáo dos archigalli, e năo Cláudio: Briem, 1951, $p$. $299,307$.

27. Segundo Cumont, 1987, p. 55, o culto a Isis fol autorizado em Roma por Calfgula, logrando de imediato, grande prestigio, em detrimento do culto dedicado a Magna Mater.

28. Segundo Carcopino, 1941 , p. 168, as divindades orientais e seus cultos, além de procurarem explicar o universo, ditavam normas de conduta para obter a imortalldade. Entre outras obras, ver: Piccaluga, 1982, p. 403-26; Gasparro, 1982, p. 467-7; Cosi, 1982; p. 492; Burckhardt, 1982, p. 188 ss., $195 \mathrm{~s}$.

29. Carcoplno, 1941, p. 168, alude a que na época de Cláudio, o estéril formalismo da religiăo oficlal romana não sattsfazla mais as exigencias das mentes romanas que buscavam na religiăo, algo mais que as formulas hablhuals; Burckhardt, 1982, p. 147; Briem, 1951, p. 318.

30. Sobre o segredo dos cultos prestados a Cibele, ver: Cosl, 1982, p. 490 s; Frazer, 1985, p. 407; Burckhardt, 1982, p. 186 s.; Turcan, 1983, p. 44-5; Briem, 1951, p. 278, 312. 
recém-instalado em Roma, optou por isolá-lo, juntamente com seu colégio sacerdotal frígio, no Palatino, proibindo os cidadãos romanos de pertencerem ao corpo sacerdotal e participarem dos rituais. A exceção era constituida pelos ludi Megalenses que estavam estruturados de acordo com os práticas da religião oficial. Afirma que nenhum romano estava autorizado a participar, nem sentia maior atração por esse culto, durante a república. Entretanto, mais adiante registra que a vigilância em torno a esse culto não conseguiu isolá-lo totalmente e que nesse momento, a religião romana iniciou um processo de ruptura com suas tradições, impossível de conter (Cumont, 1987, p. 54). Todavia, J. Bayet (Bayet, 1984, p. 139) sublinha que o culto a Cibele recebeu todas as honras da aristocracia romana.

Parece-nos não existir contradição entre os dois autores. Durante a República viveu-se uma verdadeira euforia com a chegada da deusa à Roma, seguida da vitória sobre os cartageneses. Depois, pela grande diferença existente entre o novo culto e a tradição religiosa romana, tentou-se manter o povo distante dos cultos privados a essa deusa. Quando consideramos a permanência do culto, sem quebra de continuidade em seu santuário e a celebração anual dos ludi Magelenses, não resta dúvida de que contava com razoável número de fiéis. É de supor-se que os sacerdotes trígios atraissem seguidores para iniciá-los em seus ritos privados.

A nossa inquirição encontra-se parcialmente iespondida por J. Bayet (Bayet, 1984, p. 158), ao afirmar que na época republicana existia uma forte distinção entre patrícios e plebeus, tanto na política quanto na religião, destacando a existência de deuses e cerimônias estatais exclusivas de cada classe social. Cita com exemplo o culto a Cibele que foi acolhido e promovido pelos patricios ${ }^{31}$.

F. Cumont (Cumont, 1987, p. 38-9) também esclarece a situação ao comentar que a religião oficial manteve um culto inalterado, baseado em ritos e fómulas fixas que não satisfaziam às inquietaçōes de uma época marcada por profundas mudanças, tanto nos valores governamentais como morais. Durante a República, por determinação senatorial, os cidadãos não podiam participar desse culto ${ }^{32}$. No entanto, na festa anual, era possivel que, além dos patrícios, os plebeus assistissem à procissão, como um ato, a mais, do paganismo.

No Império, o repúdio de Augusto ao cultos orientais não afetou o de Cibele, uma vez que foi assimilada à Lívia ${ }^{33}$. Mas, a importância relevante alcançada pelo culto deve-se a Cláudio que suprimiu as restrições à deusa e determinou que os archigalli seriam eleitos entre os cidadãos romanos, aumentando a pompa de suas celebrações solenes (Cumont, 1987, p. 55). 0 prestígio obtido pela deusa, na época, confirma-se pela importância de suas confrarias ${ }^{34}$ e pela expansão do culto por todo o território romano, situação essa que comprova a existência de numerosos adeptos. Vale ressaltar a opinião de F. Cumont (Cumont, 1987, p. 55) sobre os cultos orientais oriundos de civilizações em que os sacerdotes formavam a classe culta da sociedade, atrairem os pagãos com seus mistérios, festas e cantos que culminavam no êxtase liberando a alma da sujeição do corpo e logrando satisfazer a inteligência.

Por outro lado deve-se avaliar que a proibição às mulheres, de assitirem ao culto dedicado à Mitra ${ }^{35}$, fazia com que essas procurassem maciçamente o culto a Cibele, sobretudo se consideramos a influência oriental que predominava, tanto em Roma, como nas províncias. Um culto ${ }^{36}$ cheio de segredos e mistérios, além do interesse geral, exerceria especial atraçāo sobre os que se encontravam excluidos de outros cultos semelhantes.

Para J. Beaujeu, o maior público que cultuava Cibele estava representado pelas mulheres; também destaca que os romanos tradicionais rejeitavam o culto e demonstravam hostilida-

31. Segundo Carcopino, 1941, p. 168, a sabedoria consistia em tornar compativeis os cultos orientais com os interesses do Estado. Beaujeu, 19-5, p. 32; destaca que os deuses olímpicos estăo ligados aos valores culturais e polfticos $\theta$ mostra (p. 386) o importante papel desenvolvido pelo culto a Cibele, no Estado romano; Frazer, 1986, p. 412-3.

32. Sobre a proibiçăo dos cidadăos participarem do culto a Cibele ver: Turcan, 1983, p. 50, que afirma ter sido o imperador Cláudio quem determinou que o sumo sacerdote de Cibele seria um cidadăo romano; Briem, 1951, p. 299.

33. Sobre a assimilaçáo de Livia com Cibele, ver: Bayet, 1984, p. 190; Ovfdio, Eneida, IX, 77 ss., 614-20; X, 156-8, 219 ss, 252 ss., Xl, 768 ss; Turcan, 1983, p. 45; Beaujeu, 1955, p. 312 s.; Pensabene, 1972, p. 69.

34. Sobre as confrarias dos cultos a Cibele ver: Toutain, 1967, p. 82 s. 92; Carcopino, 1941, p. 78; Graillot, 1912, p. 262-4; Briem, 1951, p. 306. 
de a um ritual "digno dos bárbaros" ${ }^{37}$. De acordo com P. Pensabene ${ }^{38}$ o séquito da deusa pertencia a mais alta aristocracia, sobretudo no primeiro perlodo de sua adoção em Roma, já que no século I a.C. houve uma abertura popular nas celebrações dos ludi Megalenses.

5. O estudo das obras de Tertuliano e M. Félix levá a conclusão de que seus ataques a diferentes aspectos do paganismo visam ao mesmo objetivo - destruir o paganismo. A forma utilizada consiste na negação de seus deuses e, consequentemente, de seus ritos e cultos. Com essa intenção condenam Cibele e o ritual a ela relacionado. Este tema constitui o objetivo do nosso estudo. Fora das pretençōes deste trabalho encontram-se os ataques e outros deuses e a parte referente à doutrina cristã.

a) As alusões de Tertuliano e de M. Félix a Cibele são poucas, se consideramos os numerosos ataques a Júpiter ${ }^{39}$. Desenvolvem argumentação diferente mas com a mesma finalidade, com relatos diferentes sustentam as mesmas acusações. Que motivos levam esse apologistas a atacar Cibele? Parece-nos que os ataques a Júpiter servem melhor a seus objetivos, já que negando a divindade maior, atingem todo o panteāo romano.

Por outro lado, compreendemos que não interessa aos apologistas censusar violentamente um culto, oficialmente reconhecido pela Estado romano, que abriga e protege a outros cultos orientais ${ }^{40}$. As religiōes de mistérios e salvação apresentam pontos semelhantes, incluindo-se entre essas, o próprio cristianismo. A popularização da imortalidade, até então restrita a alguns privilegiados, é um dos novos elementos aportado por esse culto.

Em contraposição ao arcaísmo da religião oficial romana, as religiōes orientais de mistério e salvação, entre as quais se inclui o cristianismo, oferecem grande motivação aos seus seguidores e representam também forte concorrência ao cristianismo ${ }^{41}$. Não convém aos apologistas cristãos atacar fortemente essas religiōes pelas semelhanças que apresentam entre si. O cristianismo concede a salvação a todos os convertidos que sigam estritamente suas normas. $O$ cristãos consideram os seguidores dos cultos orientais como possiveis neo-cristãos, 0 que motiva os apologistas a restringirem suas acusaçōes a esses cultos. $O$ que realmente pretendem demonstrar é a ineficácia desses cultos que se identificam com o cristianismo pela promessa da vida eterna e pelos mistérios que guardam.

b) Considerando que um dos objetivos maiores da obra apologética cristã é justificar a ausência dos cristãos nos cultos pagãos, sobretudo aqueles ligados a religião oficial, é evidente que uma das maiores preocupações seja negar a divindade desses deuses. De tudo o que comentam sobre Cibele, nota-se a intenção de desmerecer a deusa, negando-lhe a categoria divina. Dal as colocações, considerando ser obra dos dalmones, à prática da castração, ritual sangrento que reune tortura e mutilação. Essa prática, impossível de ser negada pelos pagãos, constitui acusaçōes fácil de provar.

Para apagar a lembrança gloriosa da chegada de Cibele à Roma, os apologistas ironizam e ridicularizam esse acontecimento. Para demonstrar a condição humana da deusa, acusamna de ser injusta para com os romanos e impotente para impor sua vontade sobre um mortal.

Concluimos, afirmando que os apologistas atacam aspectos especfficos do culto a Cibele para concretizar o objetivo maior de sua obra - diminuir o paganismo.

35. Sobre a proibiçăo da participaçăo das mulheres no culto mitrâico, ver: Bayet, 1984, p. 230; Turcan, 1983, p. 92; Cumont, 1987, p. 62.

36. Sobre o culto a Cibele ser tachado de barulhento e bárbaro, ver: Beaujeu, 1955, p. 270; Graillot, 1912, p. 115 ss.: Carcopino, 1941, p. $303 \mathrm{~s}$.

37. Beaujeu, 1955, p. 270-1. Ver tambem Burckhardt, 1982, p. 173.

38. Sobre as celebraçoes solenes do culto prestado a Clbele, ver: Pensabene, 1972, p. 68-9; Clcero, Catăo, 45; Géllo II, 24,2; Beaujeu, 1955, p. 270; Gralllot, 1912, p. 115 ss. 144 ss.; Gasparro, 1982, p. 475.

39. Júplter $\theta$ o deus mais atacado pelos apologlstas; negando-o, acreditavam atingir todo o panteáo pagáo. Dessa forma entende-se a preocupaça de atribulr a esse deus as mais violentas e frequentes acusaçoes.

40. Sobre a proteçăo que os cultos orlentals receblam dos colégios sacerdotals de Cibele, ver: Cumont, 1987, p. 58.

41. A concorrencla entre os cultos orlentals $\theta 0$ cristianlsmo pode-se ver em: Blanchi, 1982, p. 11 s.; Frazer, 1986, p. 414, considera a rellglilo mittráica grande rival do cristlanismo por comblnar a pureza moral corn a esperança $\theta$ a imortalidade. 


\section{ABSTRACT}

The cult to Cybeles was introduced in the Roman Empire in 205-204 B.C. and was practiced ininterruptly for six centuries until the triumph of Christianism. Its exotic rytes stirred curiosity and attracted many followers, mainly women who were not allowed to participate of the mitraic cult. In spite of receiving some periodical restrictions, the cybelian cult reached its highest prestige during the rule of Emperor Claudius who suported it because he considered this cult less dangerous than the one dedicated to Isis. Tertulian and M. Felix, in their apologetical works condemned this cult, mainly its ritual. Using similar arguments or even different points of view they presented a common objective which consisted of declaring the christians innocent from the penalties imposed to them for not participating in the cults of the official religion, mainly of those rytes dedicated to the Emperor.

\section{REFERÊNCIAS BIBLIOGRÁFICAS}

ALBERTINI, E. L'empire romain. Paris: 1970.

BAYET, Jean. La religión romana. História polftica y psicológica. Madri: Cristiandad, 1984.

-. Croyances et rites dans la Rome antigue. Paris: Payot, 1971.

BEAUJEU, G. La religion romaine a l'apogée del' Empire. La politique religieuse des Antonins. Paris: 1955.

- Introduction. In: FELIX, Minucius, Octavius. Paris: Les Belles Lettres, 1974.

BIANCHI, M. Lo studio delle religion de mistera. In: La soteriologia dei culti orientali nel' Impero Romano. Leiden: 1982.

BOISSIER, G. La religion romaine d'Auguste aux Antonins. New York: 1974.

BRIEM, E. O. Societés Secretes de mystères. Paris: Payot, 1951.

BURCKHARDT, Jacob. Del paganismo al cristianismo. La época de Constantino el grande. México: Fondo de Cultura, 1982.

CORCOPINO, J. Aspects mystiques de la Rome paienne. Paris: Payot, 1941.

CID LOPES, R. M. El culto al emperador en Numídia (De Augusto a Diocleciano. Oviedo: Tese de Doutoramento. 1986.

CONTI, N. Mitologia. Murcia: 1988.

COSI, D. M. Aspecti mistici del culto de Attis. In: La poteriologie dei culti romanil lel'Impero Romano. Leiden: E. J. Brill, 1982.

CUMONT, Franz. Laz religiones Orientales y el paganismo romano. Madrid: Akal, 1987.

DOREM, M. van. Evolution des mystères phrigiens à Rome. Antiqueté classique, V. XXII, 1953.

DODDS, E. R. Paganos y cristianos en una época de angustia. La experiencia religiosa desde Marco Aurélio a Constantino. Madrid: Cristiandad. 1975.

FÉLIX, Minucius. Octavio. Tradução e introdução de J. Beaujeu. Paris: Les Belles Letres, 1974. . El Octavio. Tradução, prólogo e notas de Santos de Domingo. Madri: Aspas, s/d.

FRAZER, James George. La rama dorada. España/México: Fondo de Cultura Econômica, 1986.

GASPARRO, G. S. Soteriologie et aspects mystiques dans le culte de Cybèle et Attis. In: La soteriologie dei culti orientali nell'Impero Romano. Leiden: E. J. Brill, 1982. 
GRAILLOT, H. Le culte de Cybele, mere des dieux a Rome y dans l'Empire romain. Paris: Payot, 1912.

LAMBRECHTS, P. Auguste et la religion romaine. Latomus, Bruxelles, V. VI, 1947.

- Les fetes phrigiennes de Cibèle et d'Attis. Bull. de Inst. Belge de Rome, Roma, V. 27, 1952.

LE CLAY, Marcel. La religion romaine. Paris: Librarie Armand Colin, 1971.

MANGAS, Julio. Hispania Romana. In: TUNÕN DE LARA, M. (Diretor). Historia de España. I. Barcelona: Labor, 1980.

MEUNIER, M. Leyendas épicas de Grecia. Madrid: s/d.

PENSABENE, P. Nuove indagini nel'area del templo di Cibele sul Palatino. In: La soteriologie dei culti orientali nell'Impero Romano. Leiden: E.J. Brill, 1982.

PICCALUGA, G. Salvarsi ma non troppo. In: La soteriologie dei culti orientali nell"Impero Romano. Leiden: E. J. Brill, 1982.

PIMENTEL, Martha. Los dioses paganos en el Apologeticum de Tertuliano. In: L'Africa romana. Sassari: Gallizzi, 1989.

ROSE, H. J. Mitologia griega. Barcelona: Labor, 1973.

SEEMANN, O. Mitologia clásica ilustrada. Barcelona: Labor, 1958.

STELLA, L. A. Mitologia griega. Torino: 1956.

STEUDING, J. Mitologia griega y romana. Barcelona: 1934.

TERTULIANO. El apologeticum. Traduçāo, prólogo e notas de G. German Prado. Madrid: 1943.

- Apologia contra los gentiles en defensa de los cristianos. Tradução de Pedro Manero. Buenos Aires: Domingo E Taladriz, 1944.

- Apologétic. Tradução e introdução de Miguel Dolç. Barcelona: Fundació Bernat Metge. 1960.

—. Apologia del Cristianismo. Introdução, Tradução e notas de Cláudio Micaelli. Milano: B. M. Rizzoli, 1984.

TOUTAIN, J. Les cultes paiens dans l'Empire Romain. Roma: 1967.

TURCAN, R. Las religiones orientales en el Imperio Romano. In: PUECH, H. C. Las religiones orientales en el mundo mediterraneo y en el Oriente Próximo. Madrid: Siglo XXI, 1983. 